BLESSED EVENTS 


\section{PRINCETON STUDIES}

\section{IN CULTURAL SOCIOLOGY}

Paul J. DiMaggio
Michèle Lamont
Robert J. Wuthnow
Viviana A. Zelizer

Origins of Democratic Culture: Printing, Petitions, and the Public Sphere in Early-Modern England by David Zaret Bearing Witness: Readers, Writers,
and the Novel in Nigeria
by Wendy Griswold

Gifted Tongues: High School Debate and Adolescent Culture by Gary Alan Fine

Offside: Soccer and American Exceptionalism by Andrei S. Markovits and Steven L. Hellerman Reinventing Justice: The American Drug Court Movement by James L. Nolan, Jr.

Kingdom of Children: Culture and Contropersy in the Homeschooling Movement by Mitchell L. Stevens

Blessed Events: Religion and Home Birth in America by Pamela E. Klassen 


\section{BLESSED EVENTS}

RELIGION AND HOME BIRTH

IN AMERICA

Pamela E. Klassen

PRINCETON UNIVERSITYPRESS PRINCETONANDOXFORD 
Copyright $(\mathcal{2} 2001$ by Princeton University Press

Published by Princeton University Press, 41 William Street,

Princeton, New Jersey 08540

In the United Kingdom: Princeton University Press,

3 Market Place, Woodstock, Oxfordshire OX20 ISY

All Rights Reserved

\section{Library of Congress Cataloging-in-Publication Data}

Klassen, Pamela E. (Pamela Edith), 1967-

Blessed events : religion and home birth in America / Pamela E.

Klassen.

p. $\mathrm{cm}$. - (Princeton studies in cultural sociology)

Includes bibliographical references and index.

ISBN 0-691-08797-0 (alk. paper) -

ISBN 0-69l-08798-9 (pbk. : alk. paper)

1. Childbirth at home-Religious aspects. 2. Religion and culture.

I. Title. II. Series.

BL619.K53 2001

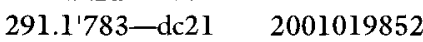

This book has been composed in Galliard

Printed on acid-free paper. $\infty$

www.pup.princeton.edu

Printed in the United States of America

$\begin{array}{llllllllll}10 & 9 & 8 & 7 & 6 & 5 & 4 & 3 & 2 & 1\end{array}$ 
for Magdalene and Isabel 

the muscle and the bone gave way and then I saw your face

now I'm a true believer in the existence of grace -Cate Friesen, "flesh and bone" 
